\title{
Relative Economics of Menthol Mint Cultivation with Existing Competitive Crop Combinations in Dudhwa Tiger Reserve Area of Uttar Pradesh
}

\author{
Shyam Prakash Singh, Teerath Raj, Anupam Singh, Deepak Kumar Verma and \\ Sanjay Kumar*
}

Technology and Business Development Division, CSIR- Central Institute of Medicinal and Aromatic Plants, Lucknow-226015, Uttar Pradesh, India

*Corresponding author: sanjaykumar@cimap.res.in (ORCID ID: 0000-0001-9647-3133)

Received: $10-07-2019$

Revised: $20-10-2019$

Accepted: 22-11-2019

\begin{abstract}
The study was undertaken to examine the relative economics of menthol mint production with existing competitive crop combinations in the Dudhwa Tiger Reserve area of Uttar Pradesh. Data were obtained through administrating of a pre-tested, well-designed survey schedule and questionnaire from 400 farmers during the agriculture year 2018-19. To accomplish the objectives of the study both descriptive analysis and project appraisal technique have been applied to study the socio-economic status of farmers along with the profile of their farm and analyze the cost, return behavior and relative profitability. The study unveiled that about 62.50 per cent farmers were having the educational qualification level of primary to postgraduate and remaining of 37.50 per cent farmers were deprived of schooling. More than three fourths 384 of the sample farmers $(96.00 \%)$ have perceived the agriculture as their main occupation, whereas only $(4.00 \%)$ of them (16 families) have selected the agriculture as their secondary occupation. The average landholding size of the respondents has been found to be 2.39 acres, which are slightly less than the national average landholding size of a household. The larger area (38.50\%) is covered under the combination of paddy-mentha-maize (42.50) followed by paddy-mustard-mentha (32.60\%), sugarcane $(22.65 \%)$ and paddy-wheat-maize (6.25\%). The majority of the respondents had the medium level of mass media exposure, extension contact and having a high level of social participation. As the annual rate of returns from investment were affected by adoption cropping pattern, method of production and prices of input and output. It is observed that some competing crops performed better in terms of total and net returns over the cost of cultivation. It is also observed that the benefit-cost ratio mentha performed better and found noticeably higher than that of other existing competitive crop combinations. Moreover, among the three major cropping patterns, the maximum net return was obtained from Paddy-Mustard-Mentha accounted for $₹ 69.81 \mathrm{~K}$ and B-C ratio was 1:1.62, it implies that farmers invest single rupee on deployed resources has been received 1.62 rupees additional as profit, it is also implied that marginal efficiency of recourses used and allocation considered as satisfactory level.
\end{abstract}

\section{Highlights}

(- Average land holding was found as small and marginal farmers.

( The maximum costs shared by irrigation, nutrients and fertilizers, land preparation, transplanting.

( Paddy-Mustard-Mentha crop rotation was found most profitable.

Keywords: Cropping pattern, mass media exposure, project appraisal, marginal efficiency, net returns

Dudhwa Tiger Reserve is a protected area of Uttar Pradesh that stretches mainly across the Lakhimpur-Kheri and Bahraich districts.
How to cite this article: Singh, S.P., Raj, T., Singh, A., Verma D.K. and Kumar, S. (2019). Relative economics of menthol mint cultivation with existing competitive crop combinations in Dudhwa tiger reserve area of Uttar Pradesh. Economic Affairs, 64(4): 725-731. 
$\underset{A \text { AESRA }}{\int_{1}}$ Singh et al.

The area is a vast alluvial flood plain traversed by heavy vegetation and numerous rivers. Prior to a decade,tribal communities of this region are closely connected with the forests and their source of income, livelihood security entirely depended on products. The glaring features of this community have low levels of education and capital assets, adopted primitive technology and traditional farming system. The community generally grows food crops are mainly used for domestic consumption. Now a day the farming community rapidly transforms their cropping pattern into income oriented and present market demand in order to get higher remunerative price of their produce.

During 2012-13 CSIR-CIMAP scientists have been conducted a survey of the tribal villages in Dudhwa Tiger Reserve and introduced the mentha cultivation in this region. Initially the crop demonstrated on selected farmer's field based on area approach. Now a days, this crop has been cultivated by the farmers around in 30 villages. In the study area, since the introduction of mentha over the last six years the extensive and rapid changes in cropping pattern and crop diversification have been took place with the object of additional and continues flow of returns from same piece of land. The farmers have been cultivated major crops like paddy, wheat, mustard, sugarcane, maize and mentha. In this region as a zaid season crop, the mentha cultivation has attracted the tribal farmers to generate additional income from the same piece of land from when mostly their land was fallow or before adoption of mint cultivation. Menthol mint is a short duration aromatic crop, well fitted between Rice-Wheat cropping systems. Usually, it requires subtropical climate and involves less cultural practices. The other factors may contribute in the adoption of mentha cultivation like continuously increase in the demand because it provides sustainable means of natural source of high value industrial raw material especially for food and cosmetic industries and opens up new possibilities for higher levels of gains for farmer with significant scope for progress in the household economy.

While the cultivation of sugarcane and paddy are dominantly affected by the wild animals found in the forest, it also requires intensive cultural practices and agri-inputs like labour, water resources, machinery power, farmers are waiting long run for returns and sometime farmers may not get remunerative price, faces troubles in selling their produce especially in case of sugarcane. In these circumstances, the cultivation of menthol mint reduces and dismantling bourdon of government to design basic infrastructure in case of surplus production of these crops in contrary the export value of menthol mint oil adds in Indian exchequer. Keeping the view in above, it was planned to estimate the cost and profitability of menthol mint with some existing competitive crop combinations in the Dudhwa Tiger Reserve area of Uttar Pradesh.

\section{MATERIALS AND METHODS}

The research area has been purposefully selected to conduct the present study on the basis of rapid increase in area under menthol mint cultivation. To accomplish the objectives of the study, the data collected from 400 farmers of all 30 villages Dudhwa Tiger Reserve where CSIR-CIMAP introduced the practices of menthol mint cultivation since 201213. The data have been collected through wellstructured survey schedule and questionnaire. The descriptive and statistical tools and technique have been adopted for analysis of collected data.

\section{Descriptive analysis}

Descriptive analysis has been applied to study the socio-economic status of farmers' along with the profile of their farm. The socio-economic status of farmers have been determine with respect to age, education, family size, caste, gender, main occupation, extension contact, media exposure, social participation, annual family income. The profile farm are being noted with respect to land holding size, farming experience and experience in mentha cultivation, cropping pattern, nature and source of irrigation, and area under mentha cultivation.

\section{Relative Profitability Analysis}

In order to find out relative profitability of Menthol mint with some competing crops (paddy, wheat, sugarcane, mustard and maize). The total cost of cultivation, gross return, net return and benefit-cost ratio has been analysed based on current market price of inputs and output. The given statistical methods as follow: 


$$
\begin{gathered}
\text { Total cost }=T F C_{i j}+T V C_{i j} \\
\text { Total return }+T R_{i j}=Y_{i j} P_{i j} \\
\text { Net return }=T R_{i j}-T C_{i j}
\end{gathered}
$$

Net return at market price $(\mathrm{NRMP})=T R-V C$ Where,

$$
\begin{aligned}
& T C_{i j}=\text { Total cost }\left(₹ \mathrm{ha}^{-1}\right) \\
& T F C_{i j}=\text { Total fixed cost }\left(₹ \mathrm{ha}^{-1}\right) \\
& T V C_{i j}=\text { Total variable cost }\left(₹ \mathrm{ha}^{-1}\right) \\
& T R_{i j}=\text { Total return }\left(₹ \mathrm{ha}^{-1}\right) \\
& P_{i j}=\text { Price }\left(₹ \mathrm{ha}^{-1}\right) \text { of } \mathrm{j}^{\text {th }} \text { the crops received by } \mathrm{i}^{\text {th }} \\
& \text { farmer }
\end{aligned}
$$$$
Y_{i j}=\text { Quantity (qtl. ha-1) produced }
$$

\section{Benefit- cost ratio (B-CR)}

To determine the benefit over the cost of cultivation of different cultivated crops in the study area, discounted method of project appraisal techniques i.e. B-CR of an investment have been used. It is ratio of all cash inflows and outflows during the production period. It measures economic efficiency of resource utilization from the standpoint of the producer. If $\mathrm{B}-\mathrm{C}$ ratio $>1$, then the total revenue is greater than the total cost, if $\mathrm{B}-\mathrm{C}$ ratio $=1$ then the total revenue is equal to the total cost and if $\mathrm{B}-\mathrm{C}$ ratio $<1$ then the revenue is less than the total cost. A decision of the $\mathrm{B}-\mathrm{C}$ ratio is to accept with a ratio above one that is $\mathrm{B}-\mathrm{C}$ ratio $>1$. It can be estimated as follows:

$$
B-C R=\sum_{t=1}^{t=n} \frac{B_{t}}{(1+r)^{t}} / \sum_{t=1}^{t=n} \frac{C_{t}}{(1+r)^{t}}
$$

Where,

$$
\begin{aligned}
& B_{t}=\text { Benefits in each year } \\
& C_{t}=\text { Cost in each year } \\
& n=\text { Number of year } \\
& i=\text { Interest rate (discount rate) }
\end{aligned}
$$

\section{RESULTS AND DISCUSSION}

Socio-economic status and profiles of farm

The socio-economic status of the respondents and profiles of their farm (Table 1) revealed that the average age of respondents was found 43.45 years. The education is an important factor, which has immense significant impact on the socio-economic life of the people. It makes the citizens highly responsible in their business activities. It enables better understanding of the work to be carried out and thereby helps better adoption of management practices and increase the productivity. But, despite of this about 62.50 per cent farmers were having the educational qualification level of primary to post graduate and remaining 37.50 per cent farmers were deprived from schooling. The family size of the farmers has influenced the farm activities as the number of persons available for carrying out the different farm operations and the mutual distribution of the workload by the members is possible. Table 1 , revealed that the average size of the family was found 6.30 people belonged to each family.

In the study area, all agricultural and allied activities were done by tribal community those belong to ST category. Usually the sample farmers were engaged in two major activities, one is agriculture and another is animal husbandry. It distinctly shows more than three fourths $(96.00 \%)$ of the sample farmers have perceived the agriculture as their main occupation and livelihood security, whereas only $(4.00 \%)$ farmers have been reported the agriculture as their secondary occupation and source of income. The average farm landholding size of the respondents has been found to be 2.39 acres, which is slightly less than the national average size of an operational holding (2.84 acres) of a household according to a rural survey carried out by the National Bank for Agriculture and Rural Development (NABARD, 2016). The average size of land devoted by respondent under mentha cultivation is about 0.64 acres.

About 61.74 per cent of the samples, farmer are having the irrigated land, while 38.26 per cent farmers hold the rain-fed lands, which are absolutely based on rain water. Usually, farmers have adopted the cropping system and take decisions about the crop diversification based on climatic condition and availability of both natural and man-made resources. The cropping pattern details are shown in table 1 , that the major crops in the study area were found paddy, wheat, sugarcane, mentha, maize and mustard respectively. The larger area $(42.50 \%)$ is covered under the combination of Paddy-Mentha-Maize followed by Paddy-MustardMentha (28.60\%), Sugarcane $(22.65 \%)$ and PaddyWheat- Maize (6.25\%). 
Majority of the respondents $(62.48 \%)$ had the medium level of mass media exposure because of their access to newspaper, pamphlets, radio, television and through attain the exhibitions, awareness and training programme, workshop, krishimelas, etc. More than four-fifth of the respondents $(87.22 \%)$ had medium to high level of extension contact because of their contact with progressive farmers, agriculture extension officer, agriculture development officer, KVK officials, cooperative, NGOs and research institute.

Table 1: Socio-economic status of respondents and profiles of their farm, $n=400$

\begin{tabular}{|c|c|c|}
\hline $\begin{array}{l}\text { Sl. } \\
\text { No. }\end{array}$ & Particulars & $\begin{array}{l}\text { Value in year, } \\
\text { average \& per } \\
\text { cent }\end{array}$ \\
\hline 1 & Age composition (year) & 43.45 \\
\hline 2 & Education (Year of studied) & \\
\hline $\mathrm{a}$ & Illiterate (Per cent) & 32.00 \\
\hline $\mathrm{b}$ & Functionally literate (Per cent) & 5.50 \\
\hline c & Primary (Per cent) & 40.50 \\
\hline $\mathrm{d}$ & Middle (Per cent) & 6.25 \\
\hline e & Secondary (Per cent) & 12.75 \\
\hline $\mathrm{f}$ & Higher secondary (Per cent) & 0.75 \\
\hline $\mathrm{g}$ & Graduate (Per cent) & 1.50 \\
\hline $\mathrm{h}$ & Post graduate (Per cent) & 0.50 \\
\hline 3 & Average family size (Number) & 6.30 \\
\hline 4 & Caste composition (Number) & \\
\hline a & General & 0.00 \\
\hline $\mathrm{b}$ & OBC & 0.00 \\
\hline $\mathrm{C}$ & SC/ST & 100.00 \\
\hline 5 & Main occupation (Per cent) & \\
\hline a & Agriculture & 96.00 \\
\hline $\mathrm{b}$ & Animal husbandry & 4.00 \\
\hline 6 & $\begin{array}{l}\text { Average farm landholding size (in } \\
\text { acres) }\end{array}$ & 2.39 \\
\hline 7 & $\begin{array}{l}\text { Average land under mentha } \\
\text { cultivation (acre) }\end{array}$ & 0.64 \\
\hline 8 & Source of irrigation (Per cent area) & \\
\hline a & Irrigated & 88.25 \\
\hline $\mathrm{b}$ & Rainfed & 11.75 \\
\hline 9 & Major cropping pattern adopted by & $y$ farmers $(\%)$ \\
\hline $\mathrm{a}$ & Paddy-Wheat- Maize & 6.25 \\
\hline $\mathrm{b}$ & Paddy-Mentha-Maize & 42.50 \\
\hline c & Paddy-Mustard- Mentha & 28.60 \\
\hline $\mathrm{d}$ & Sugarcane & 22.65 \\
\hline 10 & Extension contact (Per cent) & 87.22 \\
\hline 11 & Mass media exposure(Per cent) & 62.48 \\
\hline
\end{tabular}

12 Social participation score (Per 58.39 cent)

$13 \quad$ Farming Experience (Year) 34.45

14 Experience in mentha cultivation 3.50 (Year)

15 Annual family income (in ₹) 1.25L-1.50L

Source: Field survey.

The social participation is defined as the degree of involvement of the respondents from the mere membership to organization position and his active participation in meetings of different organization and institute. Most of the respondents (58.39\%) were having high levels of social participation because of the participation in a major social organization such as gram Panchayat, co-operative society, Panchayatsamiti, SHG, youth club, political organization, Kisan welfare club, religious institution and other organizations.

The farming experience plays a greater role to assess the outcome of existing risk in cultivation of different crops. As the majority of farming communities had average experience 34.45 years, but in case of mentha cultivation farmers have 3.50 years experience. The greater part of respondents are having an annual income of ₹ $1.25 \mathrm{~L}$ to $1.50 \mathrm{~L}$, which shows their purchasing power is an inadequate and their source of income are relatively poor and need to adoption of new and innovative technique and agricultural practices for better farming and living.

\section{Cost and return behavior}

The farmers have been cultivated number of crops in the same piece of land in different season in order to maximize returns from deploying resources like seed/sapling, land, labour and capital among alternative crops. The cost of production of different crops consist the expenses of human labour (hired as well as imputed value of family labour) + machinery labour + interest on fixed and working capital investment + expenses incurred stock and flow material inputs (cask and kind) + depreciation of machinery and equipment+ rental value of land and land revenue tax. Table 2, depicts the average total cost of different crops cultivated in the study area. The average total cost of sugarcane production per acre was incurred (₹ 60.56K), which was highest among all the major crops cultivated like Mentha (₹ 35.22K), Paddy (₹ 32.63K), Maize (₹ 28.36K) Wheat (₹ 28.28K) and Mustard (₹ 23.78K). 
Table 2: Cost structure $\left(\right.$ acre $\left.^{-1}\right)$ of major crops cultivated in the study area

\begin{tabular}{|c|c|c|c|c|c|c|c|}
\hline $\begin{array}{ll}\text { Sl. } \\
\text { No. }\end{array}$ & Cost component & Paddy & Wheat & Maize & Mustard & Mentha & Sugarcane \\
\hline \multirow[t]{14}{*}{ A. } & Variable cost (VC) & & & & & & \\
\hline & Land preparation & $2300(7.05)$ & $1690(5.98)$ & $1400(4.94)$ & $1560(6.56)$ & $1700(4.83)$ & $4000(6.60)$ \\
\hline & Nursery raising & $380(1.16)$ & - & - & - & $870(2.47)$ & - \\
\hline & Inter-cultural operations & $1160(3.56)$ & $750(2.65)$ & $1800(6.35)$ & $1080(4.54)$ & $1200(3.41)$ & $4200(6.94)$ \\
\hline & Seedling/planting materials & $900(2.76)$ & $730(2.58)$ & $1670(5.89)$ & $400(1.68)$ & $1400(3.97)$ & $4500(7.43)$ \\
\hline & Nutrients \& chemicals application & $3250(9.96)$ & $3100(10.96)$ & $2900(10.23)$ & $1820(7.66)$ & $1645(4.67)$ & $5400(8.92)$ \\
\hline & $\begin{array}{l}\text { Water source development \& } \\
\text { irrigation }\end{array}$ & $5220(16.00)$ & $3540(12.52)$ & $2800(9.87)$ & $1450(6.10)$ & $4500(12.78)$ & $4800(7.93)$ \\
\hline & Transplantation & $1600(4.90)$ & - & - & - & $1500(4.26)$ & - \\
\hline & Fencing/hedging, Watch and ward & $960(2.94)$ & $980(3.47)$ & $1100(3.88)$ & $1150(4.84)$ & - & $1600(2.64)$ \\
\hline & Harvesting & $1350(4.14)$ & $1460(5.16)$ & $1540(5.43)$ & $1500(6.31)$ & $650(1.85)$ & $12000(19.81)$ \\
\hline & Threshing/ Distillation & $1320(4.05)$ & $2100(7.43)$ & $1280(4.51)$ & $1300(5.47)$ & $7000(19.87)$ & - \\
\hline & Miscellaneous charges & $460(1.41)$ & $600(2.12)$ & $570(2.01)$ & $500(2.10)$ & $680(1.93)$ & $1600(2.64)$ \\
\hline & Interest on working capital @ 8\% & $1512(4.63)$ & $1196(4.13)$ & $1205(4.25)$ & $861(3.62)$ & $1637(4.65)$ & $3048(5.03)$ \\
\hline & Sub total & $20412(62.56)$ & $16146(57.10)$ & $16265(57.36)$ & $11621(48.88)$ & $22782(64.68)$ & 41148 (67.94) \\
\hline \multirow[t]{6}{*}{ B. } & Fixed cost (FC) & & & & & & \\
\hline & $\begin{array}{l}\text { Depreciation of farm building, } \\
\text { machinery \& eqpt. }\end{array}$ & $360(1.10)$ & $290(1.03)$ & $260(0.92)$ & $310(1.30)$ & $540(1.53)$ & $830(1.37)$ \\
\hline & Rent Value of own land & $9000(27.58)$ & $9000(31.83)$ & $9000(31.74)$ & $9000(37.85)$ & $9000(25.55)$ & $18000(29.72)$ \\
\hline & Land revenue or land tax & $240(0.74)$ & $240(0.85)$ & $240(0.85)$ & $240(1.01)$ & $240(0.68)$ & $240(0.40)$ \\
\hline & Interest on fixed capital @ 12\% & $288(0.88)$ & $280(0.99)$ & $276(0.97)$ & $282(1.19)$ & $310(0.88)$ & $344(0.57)$ \\
\hline & Sub total & $12216(37.44)$ & $12130(42.90)$ & $12092(42.64)$ & 12154 (51.12) & $12440(35.32)$ & 19414 (32.06) \\
\hline$A+B$ & Total cost $(\mathrm{TC})=\mathrm{VC}+\mathrm{FC}$ & 32628 & 28276 & 28357 & 23775 & 35222 & 60562 \\
\hline
\end{tabular}

Source: Field survey.

The total return was computed as the total value of output at current market price and the net is calculated as a total return minus total cost incurred for cultivation of particular crop. Since paddy, wheat, mustard, maize, mentha are annual crops and sugarcane found to be perennial crop. It was observed from the table 3 that the total return was high from sugarcane as (₹ $81.25 \mathrm{~K}_{\text {acre }}{ }^{-1}$ ). While the cultivator obtained maximum net return (₹ 41.06K) over the total cost from mentha production followed by sugarcane (₹ 20.69K), wheat $(10.60 \mathrm{~K})$, mustard (9.83K), paddy (₹ 8.44k) and maize (₹ 5.64). Based on the analysis of the data, three major (I) PaddyMustard-Mentha, (II) Paddy-Mentha- Maize and (III) Paddy- wheat- maize cropping systems have been identified and the details are given in table 3 . It could be observed that the highest average total cost and returns per acre are accounted for paddymustard - mentha cultivation was ₹ 85.74 and ₹ 69.81 thousand as net return followed by paddymentha- maize, which was accounted for ₹ 95.53K as average total cost and ₹ 55.14 as net return. In third cropping pattern the average total cost was incurred ₹ $81.76 \mathrm{~K}$ and obtained net returns as ₹ $32.18 \mathrm{~K}$ which is comparatively low.

The production of sugarcane in the study area is more labour intensive required high capital investment, while productions of Mustard required less capital investment as a sole cropping system. Even though, farmers obtained higher total return from sugarcane production; but in case of net return over the total cost, sugarcane occupied the second position after mentha. So, we can suggest mentha is more profitable crop. The results are also revealed that, in the study area, cropping system I (PaddyMustard-Mentha) was considered as the more profitable among the cropping systems studied, as it contributed highest returns per rupee of investment (1.62) due to the higher returns realised as a result of lower cost of cultivation.

\section{Relative profitability}

An attempt has been made to estimate the relative 
AESRA Singh et al.

Table 3: Cost, return behavior and relative profitability of mentha with Existing competitive crop combinations

\begin{tabular}{|c|c|c|c|c|c|c|c|}
\hline \multicolumn{8}{|c|}{ (A) Existing competitive crops } \\
\hline Crops & TVC & TFC & TC & TR & $\begin{array}{l}\text { NR Over } \\
\text { TC }\end{array}$ & $\begin{array}{l}\text { NR Over VC or } \\
\text { at MP }\end{array}$ & $\mathrm{B}-\mathrm{C}$ ratio \\
\hline Paddy & 20412 & 12216 & 32628 & 41070 & 8442 & 20658 & $1: 1.50$ \\
\hline Wheat & 16146 & 12130 & 28276 & 38874 & 10598 & 22728 & $1: 1.58$ \\
\hline Maize & 16265 & 12092 & 28357 & 34000 & 5643 & 17735 & $1: 1.52$ \\
\hline Mustard & 11621 & 12154 & 23775 & 33600 & 9825 & 21979 & $1: 1.65$ \\
\hline Mentha & 22102 & 12440 & 34542 & 75600 & 41058 & 53498 & $1: 1.71$ \\
\hline Sugarcane & 41148 & 19414 & 60562 & 81250 & 20688 & 40102 & $1: 1.49$ \\
\hline \multicolumn{8}{|c|}{ (B) Existing crop combination } \\
\hline I-Paddy-Mustard-Mentha & 58660 & 27078 & 85738 & 155544 & 69806 & 96884 & $1: 1.62$ \\
\hline II-Paddy-Mentha- Maize & 58779 & 36748 & 95527 & 150670 & 55143 & 91891 & $1: 1.58$ \\
\hline III-Paddy-Wheat- Maize & 52823 & 28937 & 81760 & 113944 & 32184 & 61121 & $1: 1.54$ \\
\hline
\end{tabular}

profitability of mentha production with some existing competing crop (paddy, wheat, mustard, maize, mentha, sugarcane) or crop combinations (Paddy-Mustard-Mentha), (paddy-mustard-mentha) and (paddy - wheat -maize) cultivated by farmers under the same agro-climatic conditions presented in table 2 . The relative profitability was assessed by using project appraisal technique (B-C ratio). The $\mathrm{B}-\mathrm{C}$ ratio, which is the ratio of sum of discounted total returns to the sum of discounted total costs, was estimated to be a maximum (1.71) for the mentha production and minimum (1.50) for the paddy production. It is observed that although some competing crops performed better in terms of net return but in terms of benefit-cost ratio of mentha cultivation yielded more, which was noticeably higher than that of other alternative crop or crop combinations. So, we can conclude mentha production is more financially feasible and profitable venture for farmers, both in case sole and intensive cultivation.

\section{CONCLUSION}

From the findings of the study, it can be concluded that rapid changes in cropping pattern and crop diversification in the study area with the object of abstain the supplementary income and continues the flow of returns from the same piece of land and reduces the loss against the natural and institutional risk like damage of the crop by wild animals, adverse weather condition, price instability, storage facilities. Although farmers obtained higher total return from sugarcane cultivation, while in case of net return over the total cost, sugarcane has stand into second position after amentha. The cropping system-I (paddy + mustard + mentha) was considered as the most profitable and feasible among the total three cropping systems studied, as it contributed highest returns per rupee of investment (1.62) due to the higher returns realised as a result of lower total cost. However, the farmers may be adviceto expending their area under cultivation with this crop combination in order to get higher returns.

\section{REFERENCES}

Annual report. 2016. National Bank for Agriculture and Rural Development (NABARD), pp. 28.

Gittinger, J.P. 1982. Economic Analysis of Agricultural Project, Johns Hopkins University Press. Maryland 21218, U.S.A.

Jadhav, A.D. 2009. Cost and revenue of sugarcane production in India: a price risk analysis. Co-operative Sugar, 40: 31-36.

Kudamala, S., Sharma, S. and Guleria, A. 2019. Socio-economic characteristics and problems faced by apple cultivators under with drip and without drip irrigation system. Economic Affairs, 64:451-457.

Kumar, S., Suresh, R., Singh, V. and Singh, A.K. 2011. Economic analysis of menthol mint cultivation in Uttar Pradesh: A case study of Barabanki district. Agricultural Economics Research Review,24: 346-350.

Krishna K., Tripathi, S.P. and Meena, M. 2015. Cost of cultivation of sugarcane crop in Meerut district of Uttar Pradesh. International Journal of Forestry and Crop Improvement, 6: 41-48.

Kumara, B.R., Hosamani, S.B., Desai, N.R. Megeri, S.N. and Hosamani, M.H. 2012.Costs and returns of major cropping systems in northern transition zone of Karnataka. Karnataka Journal of Agricultural Sciences, 25:208-211. 
Sharma, L. and Bhushan, B. 2019. Returns from pulses in different regions of Rajasthan at alternative price scenarios. Agricultural Science Digest, 39:1-7.

Sharma, R.S, Sanjay,K. and Tomar, V.K.S. 2012. Economics of production to Marketing of Aromatic crops in Uttar Pradesh: A Case Study. Agricultural Economic Research Review,25:155-160.

Sharma, R.S. Yogesh, K., Komal, Y., Shivam, P., Teerath, R., Vinay, Y,.Rammu, S.V., Deepak K.V., Srivastava, R.K. and Sanjay, K. 2019.Performance evaluation of newly developed variety of menthol mint at farmer's field- A case study of mint cultivation in Central Uttar Pradesh. Agricultural Science Digest, 39:67-69.
Singh, H.P.C, Singh, G.P., Rajeev, S., Kushwaha, P., Rajeev, K. and Ashutosh, K. R. 2018. Costs and Income Analysis of Maize Cultivation in Bahraich District of Uttar Pradesh, India.International Journal of Current Microbiology and Applied Sciences, 7: 1060-1065.

Singh, S.P., Gangwar, B. and Singh, M. P. 2008. Economics of sugarcane-based farming system in western Uttar Pradesh. Agricultural Economic Research Review, 21: 109117.

Thakur, R. and Mehta, P. 2014.Economic feasibility analysis of major flower crops in Himachal Pradesh state of India. International Journal of Advanced Research in Management and Social Sciences,3: 24-40. 
